\title{
Vertical distribution and migration of fish larvae in a Northeast Pacific bay
}

\author{
Lewis Haldorson ${ }^{1}$, Marc Prichett ${ }^{1}$, A. J. Paul ${ }^{2}$, David Ziemann ${ }^{3}$ \\ ${ }^{1}$ Juneau Center, School of Fisheries and Ocean Sciences, University of Alaska, 11120 Glacier Highway, Juneau, Alaska 99801, USA \\ ${ }^{2}$ Seward Marine Center, University of Alaska, PO Box 730, Seward, Alaska 99664, USA \\ ${ }^{3}$ The Oceanic Institute, Makapuu Point, PO Box 25280, Honolulu, Hawaii 96825, USA
}

\begin{abstract}
Fish larvae were collected at 6 depths in Auke Bay, southeastern Alaska, USA, on 4 days in May and June 1987. On 3 dates samples were collected between 08:00 and 13:00 h, on the other date samples were collected every $4 \mathrm{~h}$ during $24 \mathrm{~h}$. Vertical distributions of light, temperature, salinity, chlorophyll and copepod nauplii were also measured. Wind speed data were available from a nearby station. Smelt (Osmeridae) larvae, the most abundant larval fish taxon, migrated to the surface at midnight, whereas walleye pollock, flathead sole, rock sole, poacher (Agonidae) and northern smoothtongue moved deeper at dusk. During the day, most fish larvae were concentrated from 5 to $15 \mathrm{~m}$, broadly overlapping the highest abundances of copepod nauplii, although poacher and northern smoothtongue were consistently deeper ( 15 to $25 \mathrm{~m}$ ). Diurnally, smelt larvae were shallow ( 5 to $10 \mathrm{~m}$ ), and pycnocline depth accounted for more variability in their mean depth than any other biotic or physical variable. Mean depths of the other 5 most abundant taxa were in the same rank order by depth in all 4 sets of daytime samples, and depth of isotherms below the pycnocline accounted for more variation in their mean depths than did any other variable. The diurnal depth distributions we observed apparently result from temperature preferences among marine larval fishes, with descent at dusk as the most common form of diel vertical migration
\end{abstract}

\section{INTRODUCTION}

In subarctic marine ecosystems many larval fishes hatch in spring, when increasing zooplankton concentrations and higher water temperatures promote rapid growth and enhance survival (Qasim 1956, Cushing 1975). The spring phytoplankton bloom is associated with the formation of a pycnocline; consequently, fish larvae hatched in spring occupy a habitat with vertically structured physical and biotic conditions. Lasker (1978) proposed that persistent vertical stratification was necessary to develop prey concentrations required for survival of larval northern anchovy. His stable ocean hypothesis has been supported by analyses of interannual variation in survival of anchovy larvae (Peterman \& Bradford 1987), by observations that haddock larvae from stratified waters are in better condition than those from well-mixed areas (Frank \& McRuer 1989) and by indications of enhanced feeding by cod larvae in stratified waters (Tilseth \& Ellertsen 1984).
Such results imply that larval fishes are able to locate and remain in depths that have high abundances of prey. Vertical coincidence of fish larvae and their prey has been reported for cod (Ellertsen et al. 1981), walleye pollock (Kamba 1977. Nishiyama et al. 1986), mackerel (de Lafontaine \& Gascon 1989) and herring (Fortier \& Leggett 1983, Munk et al. 1989). Fish larvae, like many other planktonic organisms, perform diel vertical migrations (reviewed by Neilson \& Perry 1990), including nocturnal ascent (Kendall \& Naplin 1981, Boehlert et al. 1985), nocturnal descent (Boehlert et al. 1985, Yamashita et al. 1985, Munk et al. 1989, Lyczkowski-Shultz \& Steen 1991) and nocturnal diffusion (Kendall et al. 1987, Heath et al. 1988, Leis 1991). Larval fishes are visual predators that typically cease feeding at night when light levels fall below the minimum required for successful feeding (Blaxter 1968, Bagarinao \& Hunter 1983). To occupy depths with high prey abundance during the day, larvae performing diel vertical migrations must return to the appropriate depth when light levels rise in the morning. 
The foraging environment available to larval fishes may influence their growth and survival, and their vertical distributions will, to a large extent, determine the prey concentrations they encounter during diurnal feeding periods. As part of a study on subarctic pelagic production we examined the vertical distribution of larval fishes relative to their prey and other biotic and physical variables. Our objectives were to document. depth distributions of fish larvae during the day as the spring production cycle progressed, to identify patterns of vertical migration and to determine which physical and biotic variables may influence the location of fish larvae in a vertically stratified prey environment.

\section{STUDY AREA}

These studies were part of the APPRISE (Association of Primary Production and Recruitment in a Subarctic Ecosystem) project, a 5 yr study conducted in Auke Bay $\left(58^{\circ} 22^{\prime} \mathrm{N}, 134^{\circ} 40^{\prime} \mathrm{W}\right)$, southeast Alaska, USA (Fig. 1). Auke Bay is about $16 \mathrm{~km}^{2}$ and varies in depth from 40 to $60 \mathrm{~m}$. Until sometime in April, Auke Bay is cold $\left(<5^{\circ} \mathrm{C}\right)$, relatively saline (29 to $32 \mathrm{ppt}$ ) and isopycnal (Bruce et al, 1977, Ziemann et al. 1990). In April the water column stratifies, warms and freshens. By June the pycnocline is typically less than $10 \mathrm{~m}$ deep and surface water may be above $10^{\circ} \mathrm{C}$ and have salinity below 20 ppt (Bruce et al. 1977, Ziemann et al. 1990).

In Auke Bay the spring production cycle is initiated in early April by a phytoplankton bloom that peaks in

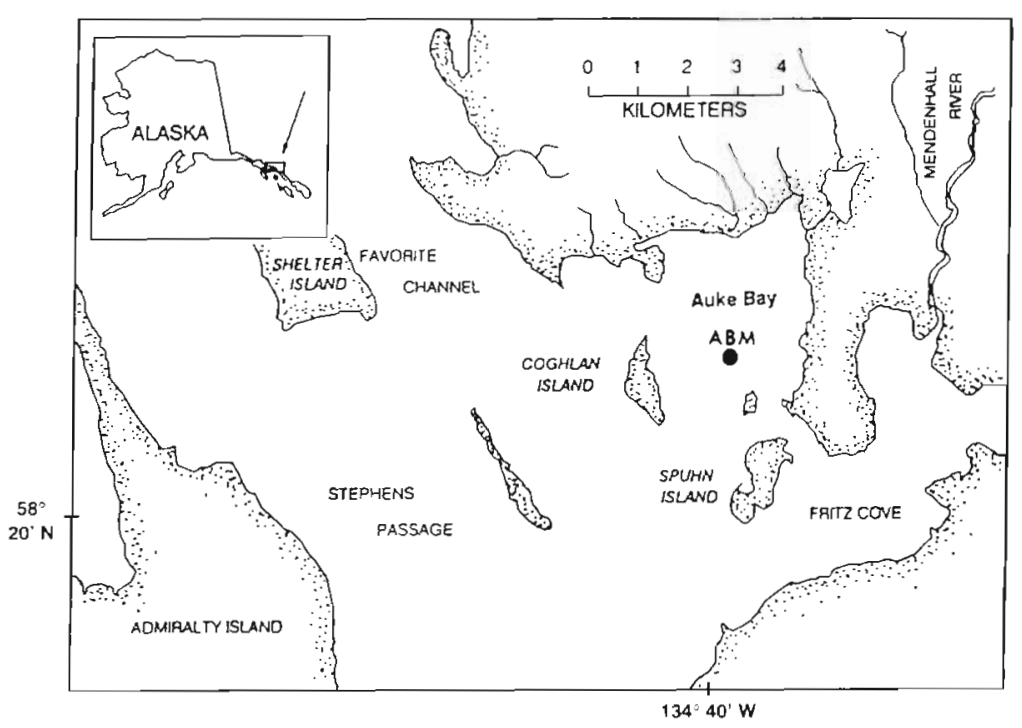

Fig. 1. Study area, Auke Bay, southeast Alaska. Samples were collected at the station designated ABM late April or early May (Williamson 1978, Ziemann et al. 1991). This is followed in May by a large increase in herbivorous copepods (Coyle et al. 1990), especially Pseudocalanus spp. (Paul et al. 1990a) and copepod nauplii (Paul et al. 1991). Copepod nauplij display considerable interannual variability in abundance, and are usually concentrated in the upper $15 \mathrm{~m}$ (Paul et al. 1991),

In Auke Bay the larvae of many fish species hatched about the time zooplankton abundance was increasing, although several species, notably Pacific sandlance Ammodytes hexapterus and rock sole Pleuronectes bilineatus, consistently occurred before the peak in phytoplankton production (Haldorson et al. 1993). Walleye pollock Theragra chalcogramma, flathead sole Hippoglossoides elassodon and smelt (Osmeridae) larvae were the most abundant taxa that hatched in synchrony with the spring zooplankton increase (Haldorson et al. 1993). Copepod nauplii in the size range 150 to $350 \mu \mathrm{m}$ were the primary prey of larval walleye pollock and flathead sole in the first month after hatching (Haldorson et al. 1989), so the abundance of nauplii of that size is reported herein.

\section{MATERIALS AND METHODS}

Larval fishes. Vertical distributions of fish larvae were determined from depth-specific horizontal tows of an opening-closing $1 \mathrm{~m}^{2}$ NIO (Tucker) trawl with $505 \mu \mathrm{m}$ mesh. The net is designed to have an effective mouth area of $1 \mathrm{~m}^{2}$ when towed at 1.5 to 2.0 knots. Daytime distributions were estimated from depth series collected between 08:00 and 13:00 h on 8 May, 15 May and 6 June 1987. Vertical migration was documented from depth series collected every $4 \mathrm{~h}$ for $24 \mathrm{~h}$ beginning at 08:00 h on 22 May 1987. Times in the following sections identify the start of a $4 \mathrm{~h}$ period of sampling. Each depth series consisted of 3 replicate samples at $0,5,10,15,20$ and $30 \mathrm{~m}$. Depth was controlled by measuring wire angle and adjusting cable length. The net was opened for $3 \mathrm{~min}$ to collect each replicate, unless rapidly changing wire angle indicated excessive clogging, in which case the net was closed early. Towing speed was about 1.5 knots. A flow meter in the net mouth was used to estimate volume filtered for each replicate. All samples were fixed immediately in $5 \%$ seawater-buffered formalin.

All fish larvae were removed from each replicate and enumerated by species or family. Identification below the family level was not used for Osmeridae, Agonidae, 
Cottidae and Cyclopteridae, as reliable keys or identification guides were not available for those species. The mean volume of water filtered per tow in the diel migration study was $155 \mathrm{~m}^{3}$. Therefore, abundance of larvae per tow was calculated as number per $100 \mathrm{~m}^{3}$ in order to standardize numbers in the same approximate range as the actual numbers in the samples (Barnett et al. 1984)

Physical and biotic measurement. Temperature and salinity profiles were determined from $40 \mathrm{~m}$ to the surface on the day preceding the date larval fish were sampled, with the exception of the first date when they were measured on 4 May. Measurements were taken with a CTD (Conductivity, Temperature, Depth) meter with built-in memory (Applied Microsystems, Inc.).

Light levels at depth were estimated based on measurements of extinction coefficients on the day preceding larval fish sampling, and on incident light at the surface on the day fish samples were collected. Extinction coefficients were determined by measuring light at depth every $2 \mathrm{~m}$ from the surface to $10 \mathrm{~m}$ with a profiling quantum scalar irradiance meter (Biophysical Instruments, Inc., Model QSP-200). Surface incident light was measured with an integrating quantum scalar irradiance meter (Biophysical Instruments, Inc., Model QSP-250) averaged every 15 min with an averaging data logger. Our estimates of incident light levels are the mean of the 15 min averaged values for the period from 06:00 to 12:00 h on the day fish larvae were sampled.

Chlorophyll concentrations were measured on the day preceding larval fish sampling. Water samples were collected at depths of $0,2,4,6,8,10,15,20,25$, 30 and $35 \mathrm{~m}$ with a 51 Niskin bottle. Chlorophyll concentrations were determined with the fluorometric method for acetone-extracted samples (Strickland \& Parsons 1972).

Microzooplankton samples were collected at $0,5,10$, 15,20 and $30 \mathrm{~m}$ depths with a $30 \mathrm{l}$ Niskin bottle on the day preceding larval fish sampling. Water from the bottle was passed through a $64 \mu \mathrm{m}$ mesh sieve and the concentrated samples were preserved in buffered formalin. Copepod nauplii were measured and counted in length categories of $<150,150$ to 350 and $>350 \mu \mathrm{m}$.

Data analyses. The null hypothesis that larvae were evenly distributed over depth in each horizontal sample series was tested with the Kruskal-Wallis nonparametric test or with ANOVA on $\log (x+1)$ transformed data. ANOVA was used for the most abundant taxa; however, we used the Kruskal-Wallis test for others because the frequent occurrence of zero values violates assumptions of normality in a way that is not corrected by transformation (Barnett et al. 1984). Data are reported as means with standard errors for consistency within tables. If results of ANOVA were significant $(\mathrm{p}<0.05)$, we used Scheffé's a posteriori contrast tests, corrected for multiple pairwise tests, to identify the pattern of aggregation, based on groupings of depths with no significant differences among group members. If a given depth could be assigned to either of 2 groups (i.e. did not differ significantly from the depths in either group) it was included in the group with which it had the lowest average $F$-values.

To test the null hypothesis that time of day had no effect on vertical distributions of fish larvae, we used the heterogeneity chi-square test (McCleave et al. 1987). If this test was significant, we examined the standardized residuals for each time period to identify those depths that were responsible for most of the heterogeneity among times.

The mean depth of larvae in each sample series was calculated as the center of density:

$$
Z=\sum_{i=1}^{n} P_{i} Z_{i}
$$

where $Z_{i}$ is the depth of the $i$ th sample and $P_{i}$ is the proportion of larvae at depth $i$ (Fortier \& Leggett 1983). We examined the relationship between physical and biotic variables and the distribution of fish larvae on the 4 sample dates with simple linear regression, with mean depth of larvae as the dependent variable. The independent variables were depth of the chlorophyll maximum, mean depth of copepod nauplii (150 to $350 \mu \mathrm{m})$, depth of the pycnocline, depth of the 5 and $6^{\circ} \mathrm{C}$ isotherms, depth of the $1 \times 10^{15}$ quanta $\mathrm{cm}^{-2} \mathrm{~s}^{-1}$ irradiance level and wind speed.

\section{RESULTS}

\section{Physical conditions}

In southeast Alaska, 1987 was a year of unusually stormy, cloudy weather (Ziemann et al. 1991); consequently, in early May the pycnocline was poorly developed with a weak temperature and salinity discontinuity near $15 \mathrm{~m}$ (Fig. 2). During May the surface layer actually cooled, as the $6^{\circ} \mathrm{C}$ isotherm rose from $15 \mathrm{~m}$ during the first week of May to $5 \mathrm{~m}$ in the third week (Fig. 3). However, by early June surface warming had occurred and a relatively strong pycnocline was at 5 to $10 \mathrm{~m}$ and temperature isotherms turned sharply deeper.

Day length was increasing during the sampling period. Sunrise and sunset (Pacific daylight time) were at $05: 48 \mathrm{~h}$ and $22: 03 \mathrm{~h}$ on $8 \mathrm{May}$ and at $04: 58 \mathrm{~h}$ and $22: 56 \mathrm{~h}$ on 5 June. On the days larval fish were sampled there was considerable variability in light at the surface due to weather patterns over southeast Alaska. On $8,15 \& 22$ May and 5 June the average 


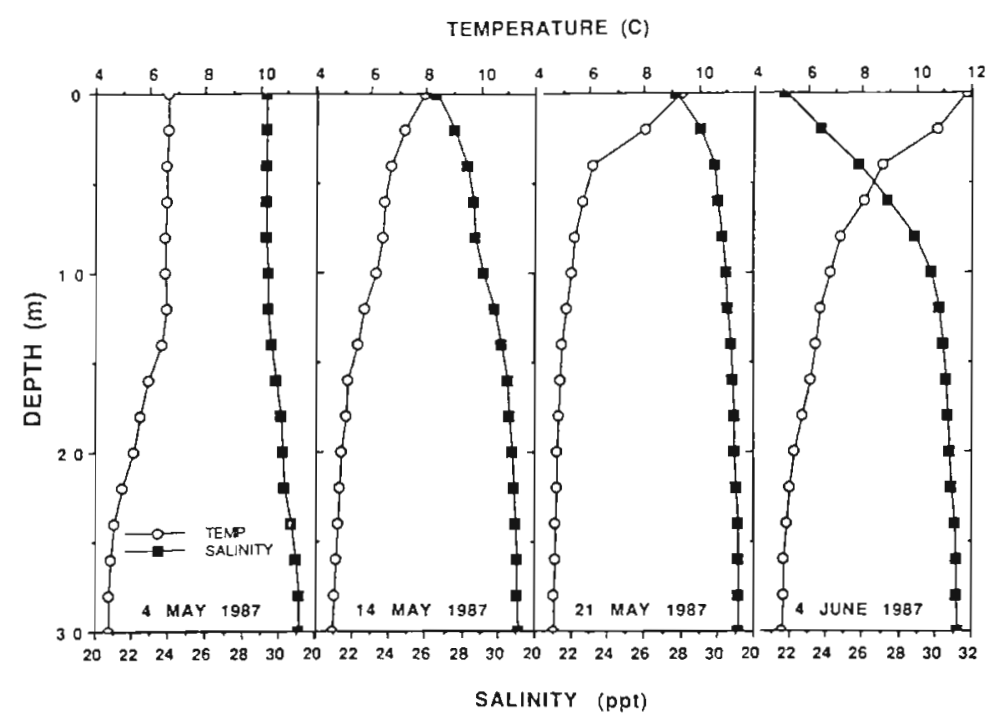

Fig. 2. Temperature and salinity depth-profiles at Stn ABM in Auke Bay, Alaska on 4 dates in 1987

incident light for the period from $06: 00$ to $12: 00 \mathrm{~h}$ was $47.9,101.4,40.7$ and $27.8\left(\times 10^{15}\right.$ quanta $\left.\mathrm{cm}^{-2} \mathrm{~s}^{-1}\right)$. Extinction coefficients on 7,14\& 21 May and 4 June were $0.73,0.49,0.44$ and 0.39 ; consequently, highest light levels at all depths occurred on 15 May, while the lowest levels were in the preceding week (Table 1).

To assess effects of the physical environment on depth distributions of larval fishes, we used depth of the pycnocline determined from Fig. 2, depth of the 5 and $6^{\circ} \mathrm{C}$ isotherms, and the depth of the $1 \times 10^{15}$ quanta $\mathrm{cm}^{-2}$ $\mathrm{s}^{-1}$ isolume. The 2 isotherms and the isolume values were selected because they occurred in approximately the same depth range as the mean depths of larval

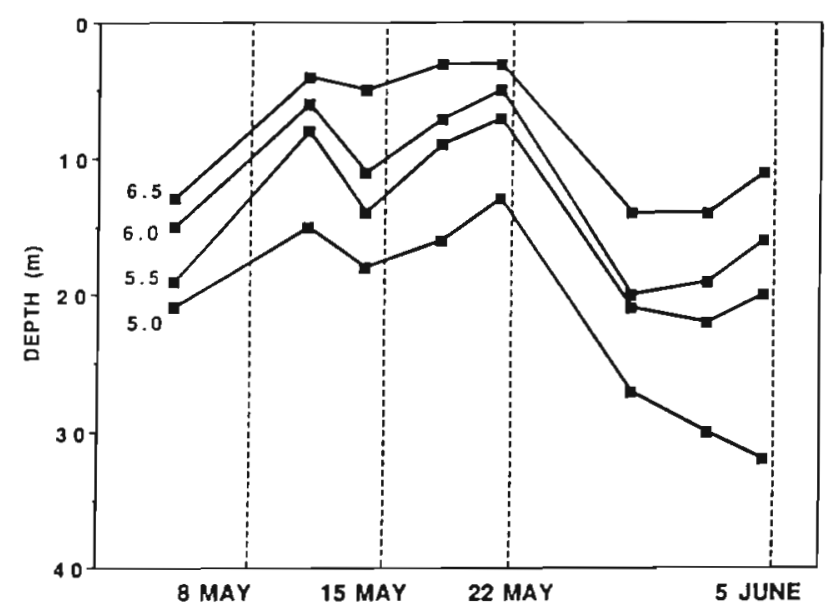

Fig. 3. Depth of isotherms in Auke Bay over the sampling period. Dates when larval fishes were sampled are indicated fishes. Below the pycnocline water temperatures gradually decreased from over $6^{\circ} \mathrm{C}$ to just above $4^{\circ} \mathrm{C}$ (Figs. $2 \& 3$ ). The 2 isotherms were chosen to represent the temperature structure of the water column below the pycnocline. We also used the mean wind speed for the date larval fishes were sampled, as recorded in NOAA weather records at the Juneau airport about $4 \mathrm{~km}$ east of Auke Bay (Table 2).

\section{Biotic conditions}

The spring production cycle was in a state of transition during the month of this study. The initial sampling of vertical distributions occurred at the end of the phytoplankton bloom, while the last 2 sampling dates were during the annual increase in herbivorous copepods (Fig. 4). Chlorophyll was typically at highest concentration in the upper $10 \mathrm{~m}$, with a chlorophyll maximum of over $20 \mathrm{mg} \mathrm{m}^{-3}$ on all but the last sampling date (Fig. 5). The mean depth of nauplii (150 to $350 \mu \mathrm{m}$ lengths) occurred from 5 to $10 \mathrm{~m}$. On the last 2 sampling dates there were relatively few nauplii available, as maximum densities were below 20 ind. $1^{-1}$ (Fig. 5).

We used depth of the chlorophyll maximum and mean depth of copepod nauplii to study effects of biotic variables on depth distributions of larval fishes (Table 2).

\section{Vertical migration: 22 to 23 May}

Larval fishes most abundant in the $24 \mathrm{~h}$ vertical migration study were osmerids, walleye pollock, agonids, northern smoothtongue, flathead sole and rock sole. Other species were at densities too low for us to assess their patterns of vertical migration.

Table 1. Amounts of light (units $=10^{15}$ quanta $\mathrm{cm}^{-2} \mathrm{~s}^{-1}$ ) at depths of $0,5,10$ and $15 \mathrm{~m}$ in Auke Bay on 8, 15, 22 May and 5 June 1987, calculated from the average incident light from 06:00 to 12:00 h on those dates (the light at depth 0 in the table), and extinction coefficients $(k)$ measured on the preceding day

\begin{tabular}{|ccccc|}
\hline \multirow{2}{*}{$\begin{array}{c}\text { Depth } \\
\text { (m) }\end{array}$} & 8 May & 15 May & 22 May & 5 June \\
\hline 0 & 47.9 & 101.4 & 40.7 & 27.8 \\
5 & 1.24 & 8.75 & 4.51 & 3.95 \\
10 & 0.03 & 0.76 & 0.50 & 0.56 \\
15 & 0.001 & 0.065 & 0.055 & 0.080 \\
\hline
\end{tabular}


Table 2. Depth $(\mathrm{m})$ distributions of physical and biotic variables measured in Auke Bay, Alaska, on 4 dates from 4 May to 5 June 1987, and used as independent variables in linear regression analyses with mean depth of larval fishes as the dependent variable

\begin{tabular}{|lcccc|}
\hline Variable & $4-7$ May & 14 May & 21 May & 5 June \\
\hline Pycnocline & 15 & 10 & 5 & 8 \\
$6^{\circ} \mathrm{C}$ isotherm & 15 & 11 & 5 & 16 \\
$5^{\circ} \mathrm{C}$ isotherm & 21 & 18 & 13 & 32 \\
Light $\left(1 \times 10^{15}\right.$ quanta cm $\left.^{-2} \mathrm{~s}^{-1}\right)$ & 5 & 9 & 8 & 8 \\
Wind speed (miles h & -1 \\
Phytoplankton (maximum) & 4.8 & 11.2 & 6.2 & 8.1 \\
Nauplii (mean depth) & 3 & 10 & 10 & 5 \\
& 6.8 & 10.8 & 10.0 & 10.5 \\
\hline
\end{tabular}

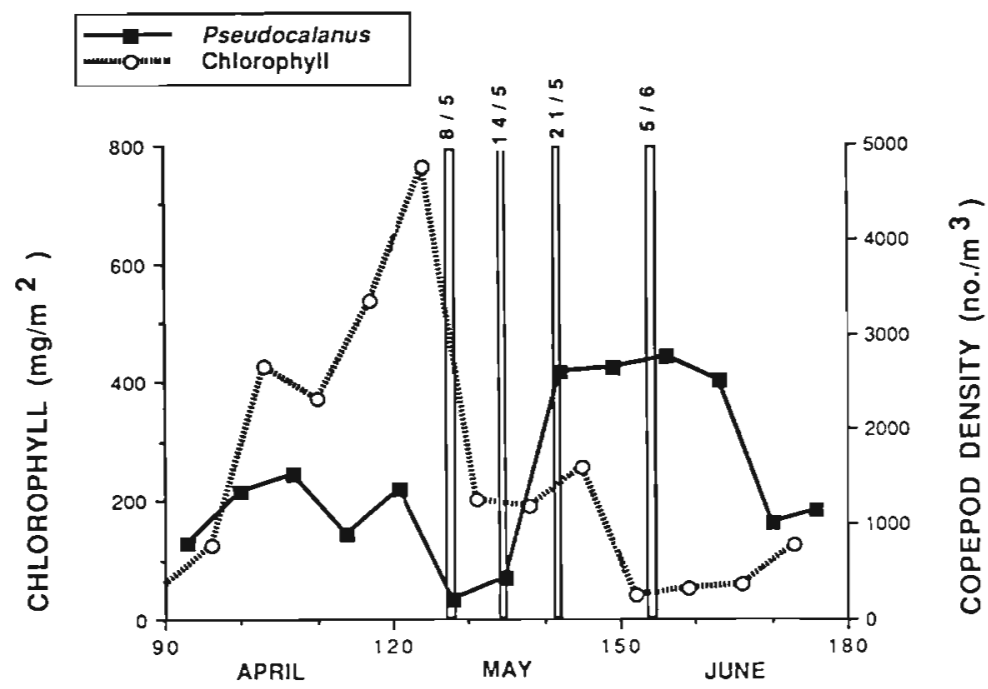

Fig. 4. Densities of chlorophyll and Pseudocalanus spp. copepods during spring 1987 (data from Coyle \& Paul 1990, Ziemann et al. 1990), with marks on the dates larval fishes were sampled for vertical distribution studies

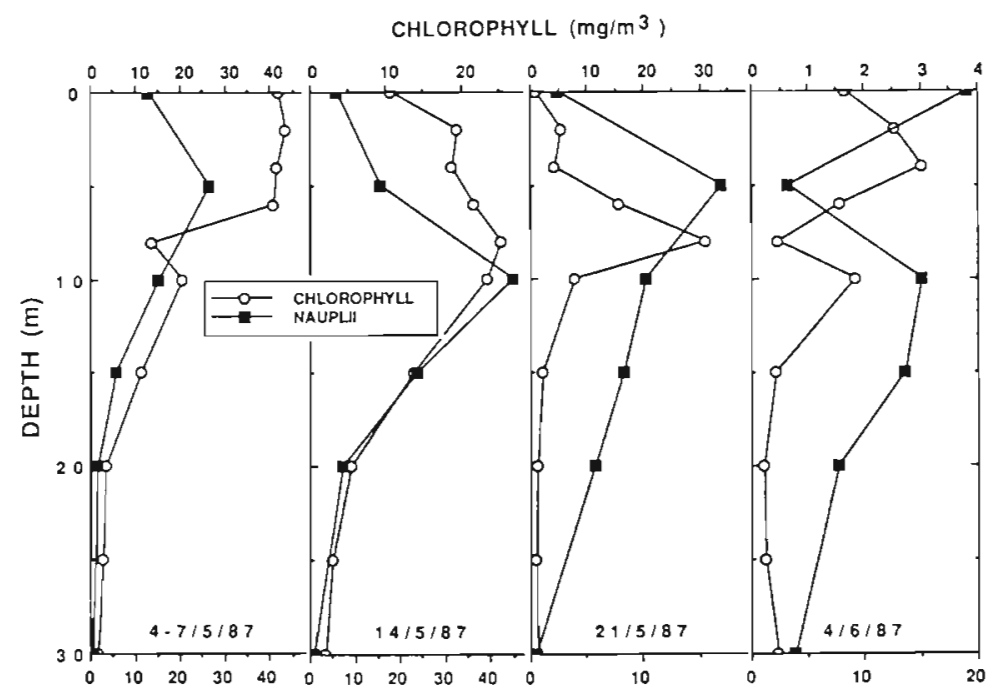

Fig. 5. Vertical distributions of chlorophyll and copepod nauplii (150 to $350 \mu \mathrm{m}$ lengths) in Auke Bay prior to collection of larval fish samples
Smelt (Osmeridae)

Osmerids were the most abundant fish larvae in the vertical migration study. All time periods had significant differences among depths $(p<0.001)$. Larvae were concentrated at $5 \mathrm{~m}$ during the day and at the surface at midnight (Fig. 6A), whereas in the other time periods they were apparently more diffuse, as their abundances tended to be homogeneous through middepths (Table 3). There was a significant difference among the 6 time periods, due largely to concentration at the surface at midnight (24:00 h).

\section{Walleye pollock Theragra chalcogramma}

During the brightest daylight hours (08:00 to $16: 00 \mathrm{~h}$ ) walleye pollock larvae were found in highest numbers at 5 to $10 \mathrm{~m}$ depths (Fig. 6B). In the evening they descended and remained relatively deep through the night, with highest numbers at 15 to $20 \mathrm{~m}$ during the $20: 00$ and $24: 00 \mathrm{~h}$ periods. By early morning $(04: 00 \mathrm{~h})$ they had ascended to typical daytime depths of 5 to $15 \mathrm{~m}$. Differences among depths were significant at all times, with surface and deeper strata forming homogenous groupings in most of the time periods (Table 3 ). At 20:00 h all depths formed a homogeneous set (based on a posteriori Scheffé tests), even though ANOVA found a significant difference among depths. This occurred because of the relatively low power of the a posteriori test.

Among time periods there was a highly significant difference in depth distribution, mainly because of higher than expected numbers at 5 or $10 \mathrm{~m}$ depths at 08:00, $12: 00,16: 00$ and $04: 00 \mathrm{~h}$, and at 15 to $20 \mathrm{~m}$ at 20:00 and 24:00 h.

\section{Flathead sole Hippoglossoides elassodon}

During the day flathead sole were concentrated at $5 \mathrm{~m}$ (Fig. 6C). At twilight they appear to descend somewhat, but still had peak concentrations at 5 to $10 \mathrm{~m}$. This distribution apparently continues through the night, although at midnight there were relatively high numbers at the surface. Differences among depths were nonsignificant only at 20:00 h $(p=0.07)$, and margin- 

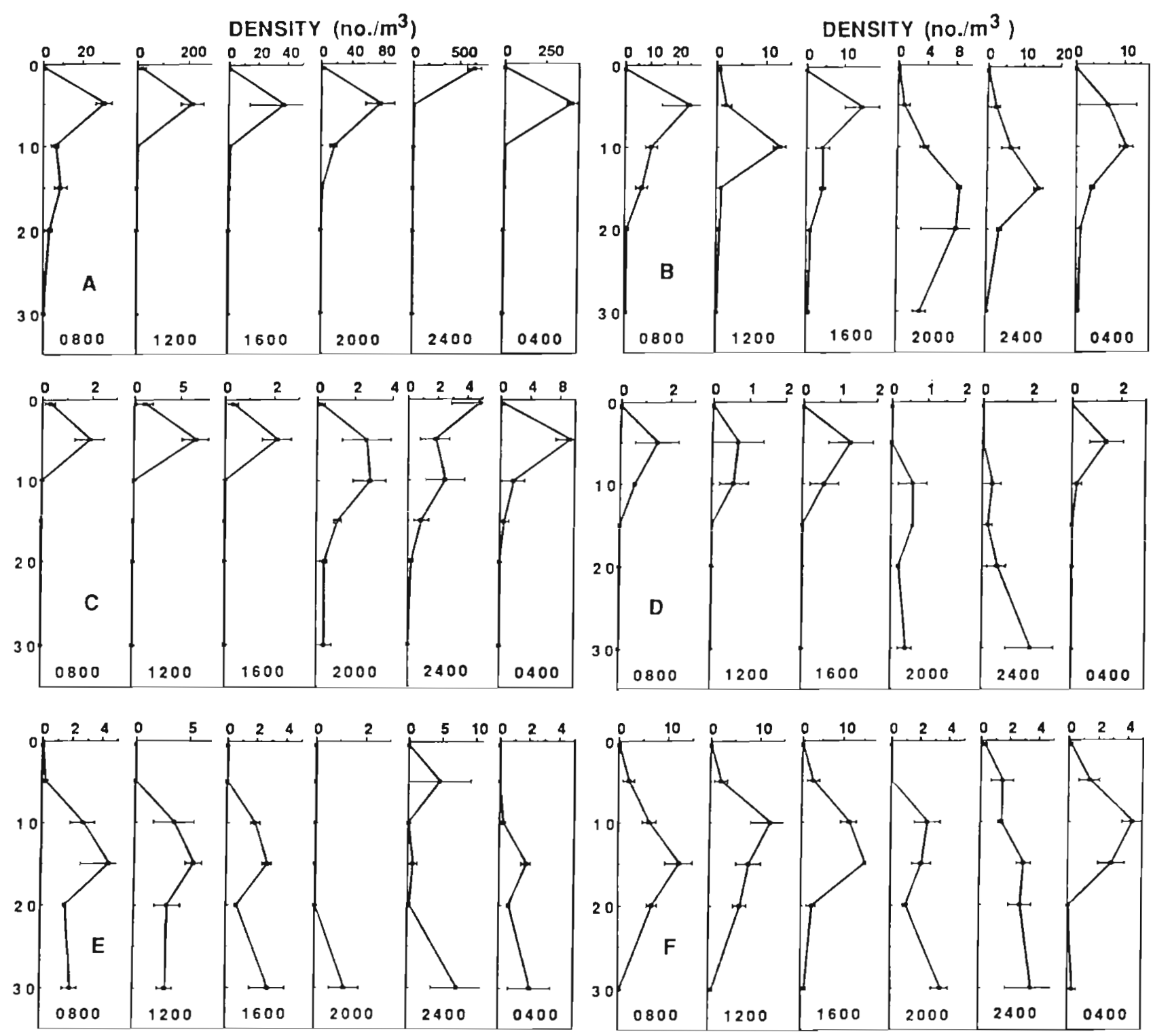

Fig. 6. Vertical abundance profiles of larval fishes in 6 time intervals beginning at 08:00 h on $22 \mathrm{May} 1987$ and ending at 08:00 h on 23 May 1987. Data points are the mean of 3 replicates, error bars are 1 SE. Species: A, osmerids; B, walleye pollock; $C$, flathead sole; $D$, rock sole; $E$, northern smoothtongue; $F$, agonids

ally significant at $24: 00 \mathrm{~h}(\mathrm{p}=0.046)$. At $24: 00 \mathrm{~h}$ all depths were homogeneous in the paired a posteriori Scheffé tests (Table 3).

There was a highly significant difference in depth distribution among the 6 time periods, due to high numbers at $5 \mathrm{~m}$ at 08:00,12:00,16:00 and 04:00 h, and occurrence of larvae at the surface at 24:00 h.

\section{Rock sole Pleuronectes bilineatus}

By mid-May, rock sole were at relatively low density. During daylight they occurred mainly at 5 to
$10 \mathrm{~m}$, with highest numbers consistently at $5 \mathrm{~m}$ (Fig. 6D). At twilight (20:00 h) they were deeper, and by midnight were concentrated at $30 \mathrm{~m}$. By early morning they were again found mainly at $5 \mathrm{~m}$. Differences among depths were significant only at 04:00 and 08:00 h, however even at those times all of the depths were homogeneous in a posteriori testing (Table 3).

There was a significant difference in depth distribution among time periods, principally because of relatively high numbers at $30 \mathrm{~m}$ at $24: 00 \mathrm{~h}$, and at 5 to $10 \mathrm{~m}$ at 08:00, 12:00, 16:00 and 04:00 h. 
Table 3. Groupings of homogeneous depths in diel depth studies conducted on 22 to 23 May 1987 in Auke Bay, Alaska, for 6 species of larval fishes, as determined by Scheffé's a posteriori F-tests on log $(x+1)$-transformed data. All: no significantly different pairs among all of the pairwise comparisons. "No significant difference among depths at that time when tested by ANOVA

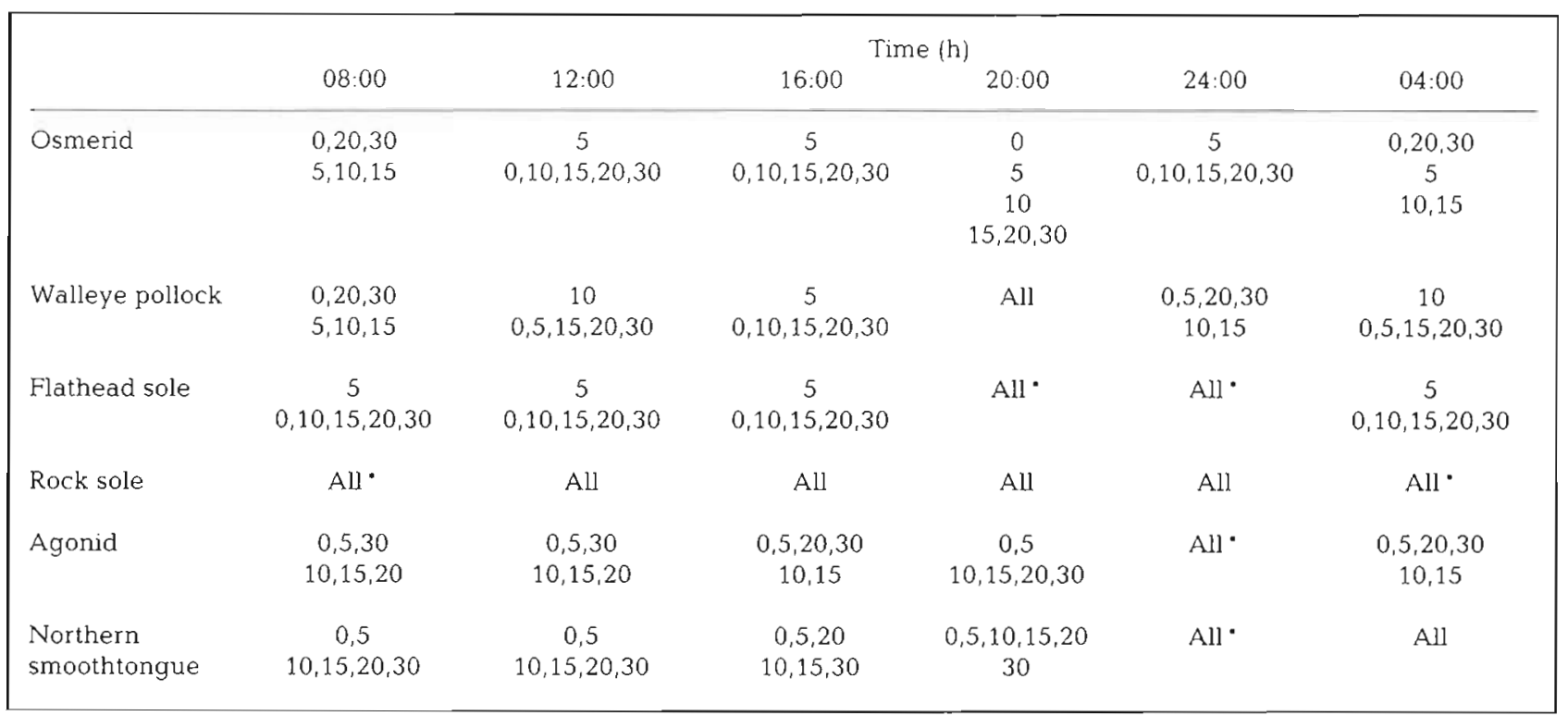

\section{Poachers (Agonidae)}

Poachers were distributed somewhat deeper than most other species, with peak daytime abundances from 10 to $20 \mathrm{~m}$ (Fig. 6F). At twilight they descended, as their highest numbers in the 20:00 and 24:00 h periods were at $30 \mathrm{~m}$. By early morning $(04: 00 \mathrm{~h})$ they had reoccupied daytime depths of 5 to $15 \mathrm{~m}$. Differences among depths were significant at all times except 24:00 $\mathrm{h}(\mathrm{p}=0.15)$. Mid-depth strata ( 5 to $15 \mathrm{~m}$ ) tended to form homogeneous groupings in a posteriori tests (Table 3).

There was a significant difference among depth distributions in the 6 time periods, due mainly to deeper distributions in the darkest periods $(20: 00,24: 00 \mathrm{~h})$.

\section{Northern smoothtongue Leuroglossus schmidti}

Larvae of this deep-sea smelt species (Bathylagidae) displayed vertical migration similar to poachers, with daytime densities highest from 10 to $20 \mathrm{~m}$, although even during the day there were relatively high numbers at $30 \mathrm{~m}$ (Fig. 6E). At twilight (20:00 h) these larvae apparently descended, as they were found only at $30 \mathrm{~m}$. At 24:00 h there were notable numbers at $5 \mathrm{~m}$, and by $04: 00 \mathrm{~h}$ they were commonly occurring above $30 \mathrm{~m}$. Differences among depths were significant in all time periods except 24:00 h. During the day depths below $10 \mathrm{~m}$ tended to form a homogenous group (Table 3). Difference in depth distribution among the 6 time periods was significant, with most of the variability due to deeper distribution at night.

During daylight hours mean depth of the above taxa ranged from 15 to $20 \mathrm{~m}$ for northern smoothtongue to about $5 \mathrm{~m}$ for osmerids and flathead sole (Fig. 7). The 6 taxa remained in approximately the same rank order by depth throughout the $24 \mathrm{~h}$ period. Osmerids rose to the surface at midnight, whereas the other 5 taxa moved deeper around sunset (20:00 h), followed by ascent back

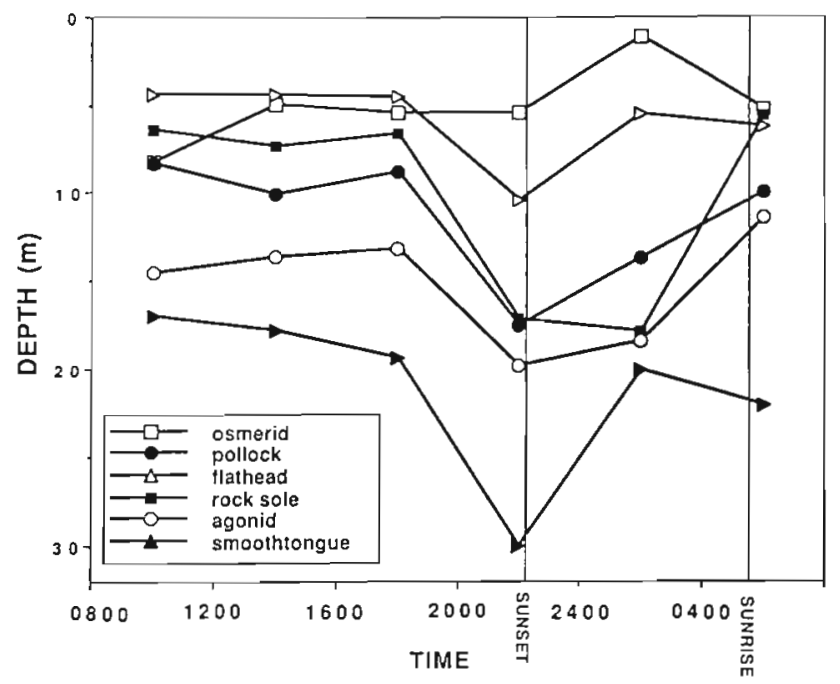

Fig. 7. Mean depths of the 6 most abundant taxa in Auke Bay in 6 sampling periods from 08:00 h on 22 May 1987 through 08:00 h on 23 May 1987. Sunset and sunrise are indicated with vertical lines 
Table 4. Mean densities, in numbers per $100 \mathrm{~m}^{3}$, of fish larvae by depth, with standard errors (in parentheses) and results of statisticaI tests for differences among depths for samples collected on 8 May 1987 . Underlined probabilities resulted from ANOVA on $\log (x+1)$-transformed data, others are from Kruskal-Wallis nonparametric tests

\begin{tabular}{|c|c|c|c|c|c|c|c|}
\hline \multirow[t]{2}{*}{ Taxa } & \multicolumn{6}{|c|}{ Depth (m) } & \multirow[t]{2}{*}{$p$} \\
\hline & 0 & 5 & 10 & 15 & 20 & 30 & \\
\hline Smelt (Osmeridae) & $\begin{array}{c}1.8 \\
(0.4)\end{array}$ & $\begin{array}{l}14.3 \\
(4.0)\end{array}$ & $\begin{array}{c}1.0 \\
(0.7)\end{array}$ & $\begin{array}{c}0.6 \\
(0.4)\end{array}$ & $\begin{array}{c}0 \\
(0)\end{array}$ & $\begin{array}{c}0 \\
(0)\end{array}$ & $\leq 0.001$ \\
\hline $\begin{array}{l}\text { Walleye pollock } \\
\text { Theragra chalcogramma }\end{array}$ & $\begin{array}{c}0.1 \\
(0.1)\end{array}$ & $\begin{array}{c}2.4 \\
(0.7)\end{array}$ & $\begin{array}{c}7.8 \\
(1.2)\end{array}$ & $\begin{array}{c}8.4 \\
(1.3)\end{array}$ & $\begin{array}{c}1.1 \\
(1.1)\end{array}$ & $\begin{array}{c}0.1 \\
(0.1)\end{array}$ & $\leq 0.001$ \\
\hline Poacher (Agonidae) & $\begin{array}{c}0 \\
(0)\end{array}$ & $\begin{array}{c}0.4 \\
(0.2)\end{array}$ & $\begin{array}{c}1.6 \\
(0.9)\end{array}$ & $\begin{array}{c}5.4 \\
(1.1)\end{array}$ & $\begin{array}{c}1.1 \\
(0.6)\end{array}$ & $\begin{array}{c}0.3 \\
(0.3)\end{array}$ & $\underline{0.004}$ \\
\hline $\begin{array}{l}\text { Slender cockscomb } \\
\text { Anoplarchus insignis }\end{array}$ & $\begin{array}{c}1.2 \\
(0.7)\end{array}$ & $\begin{array}{c}1.3 \\
(0.7)\end{array}$ & $\begin{array}{c}0 \\
(0)\end{array}$ & $\begin{array}{c}0 \\
(0)\end{array}$ & $\begin{array}{c}0 \\
(0)\end{array}$ & $\begin{array}{c}0 \\
(0)\end{array}$ & 0.006 \\
\hline $\begin{array}{l}\text { Northern ronquil } \\
\text { Ronquilus jordani }\end{array}$ & $\begin{array}{c}1.3 \\
(0.4)\end{array}$ & $\begin{array}{c}0 \\
(0)\end{array}$ & $\begin{array}{l}0 \\
(0)\end{array}$ & $\begin{array}{c}0.2 \\
(0.2)\end{array}$ & $\begin{array}{c}0 \\
(0)\end{array}$ & $\begin{array}{c}0 \\
(0)\end{array}$ & 0.013 \\
\hline $\begin{array}{l}\text { Sandlance } \\
\text { Ammodytes hexapterus }\end{array}$ & $\begin{array}{c}0.6 \\
(0.4)\end{array}$ & $\begin{array}{c}0.4 \\
(0.2)\end{array}$ & $\begin{array}{c}0.3 \\
(0.3)\end{array}$ & $\begin{array}{c}0 \\
(0)\end{array}$ & $\begin{array}{c}0.1 \\
(0.1)\end{array}$ & $\begin{array}{c}0 \\
(0)\end{array}$ & 0.362 \\
\hline $\begin{array}{l}\text { Northern smoothtongue } \\
\text { Leuroglossus schmidti }\end{array}$ & $\begin{array}{c}0.1 \\
(0.1)\end{array}$ & $\begin{array}{c}0 \\
(0)\end{array}$ & $\begin{array}{c}2.8 \\
(1.1)\end{array}$ & $\begin{array}{c}2.4 \\
(1.1)\end{array}$ & $\begin{array}{c}0.9 \\
(0.1)\end{array}$ & $\begin{array}{c}1.6 \\
(0.2)\end{array}$ & $\underline{0.003}$ \\
\hline $\begin{array}{l}\text { Rock sole } \\
\text { Pleuronectes bilineatus }\end{array}$ & $\begin{array}{c}0 \\
(0)\end{array}$ & $\begin{array}{c}0.8 \\
(0.6)\end{array}$ & $\begin{array}{c}1.0 \\
(0.7)\end{array}$ & $\begin{array}{c}0.1 \\
(0.4)\end{array}$ & $\begin{array}{c}0.3 \\
(0.1)\end{array}$ & $\begin{array}{c}0 \\
(0)\end{array}$ & 0.263 \\
\hline $\begin{array}{l}\text { Flathead sole } \\
\text { Hippoglossoides elassodon }\end{array}$ & $\begin{array}{c}0 \\
(0)\end{array}$ & $\begin{array}{c}1.1 \\
(0.6)\end{array}$ & $\begin{array}{c}0 \\
(0)\end{array}$ & $\begin{array}{c}0 \\
(0)\end{array}$ & $\begin{array}{c}0 \\
(0)\end{array}$ & $\begin{array}{c}0 \\
(0)\end{array}$ & 0.060 \\
\hline $\begin{array}{l}\text { Starry flounder } \\
\text { Platichthyes stellatus }\end{array}$ & $\begin{array}{c}1.0 \\
(0.3)\end{array}$ & $\begin{array}{c}0.6 \\
(0.6)\end{array}$ & $\begin{array}{c}0 \\
(0)\end{array}$ & $\begin{array}{c}0 \\
(0)\end{array}$ & $\begin{array}{c}0 \\
(0)\end{array}$ & $\begin{array}{c}0 \\
(0)\end{array}$ & 0.344 \\
\hline $\begin{array}{l}\text { Sand sale } \\
\text { Psettichthys melanostictus }\end{array}$ & $\begin{array}{c}0 \\
(0)\end{array}$ & $\begin{array}{c}0.4 \\
(0.4)\end{array}$ & $\begin{array}{c}0 \\
(0)\end{array}$ & $\begin{array}{c}0 \\
(0)\end{array}$ & $\begin{array}{c}0 \\
(0)\end{array}$ & $\begin{array}{c}0 \\
(0)\end{array}$ & 0.416 \\
\hline $\begin{array}{l}\text { Sculpins (Cottidae) } \\
>5 \text { species }\end{array}$ & $\begin{array}{c}0.5 \\
(0.5)\end{array}$ & $\begin{array}{c}6.2 \\
(0.4)\end{array}$ & $\begin{array}{c}4.8 \\
(0.6)\end{array}$ & $\begin{array}{c}3.2 \\
(0.8)\end{array}$ & $\begin{array}{c}0.8 \\
(0.6)\end{array}$ & $\begin{array}{c}0 \\
(0)\end{array}$ & 0.009 \\
\hline Snailfishes (Cyclopteridae) & $\begin{array}{c}0 \\
(0)\end{array}$ & $\begin{array}{c}0 \\
(0)\end{array}$ & $\begin{array}{c}0 \\
(0)\end{array}$ & $\begin{array}{c}0.6 \\
(0.4)\end{array}$ & $\begin{array}{c}0.3 \\
(0.1)\end{array}$ & $\begin{array}{c}0 \\
(0)\end{array}$ & 0.084 \\
\hline
\end{tabular}

to daytime depths either during the night or in the early morning. By sunrise the distribution of mean depths was very similar to the distribution at the start of the $24 \mathrm{~h}$ sampling in the preceding morning (Fig. 7).

\section{Daytime depth distribution of fish larvae}

$$
8 \text { May }
$$

On 8 May most fish larvae were located at 5 to $15 \mathrm{~m}$ (Table 4). Walleye pollock were the most abundant larvae collected, followed by osmerids and cottids. Osmerids were the only larvae concentrated in depths less than $10 \mathrm{~m}$. Walleye pollock, agonids, and northern smoothtongue were concentrated at 10 to $15 \mathrm{~m}$. Northern smoothtongue was notable in having the deepest distribution, with relatively high numbers at $30 \mathrm{~m}$. Samples from $30 \mathrm{~m}$ contained few other species.

\section{May}

By mid-May osmerids were increasing in number, and were the most abundant taxon. Other species present in relatively high numbers were walleye pollock, flathead sole and agonids, all of which were more abundant than in the preceding week (Table 5). Osmerids and flathead sole were concentrated in relatively shallow water (0 to $10 \mathrm{~m}$ depth), walleye pollock somewhat deeper $(10$ to $15 \mathrm{~m})$ and agonids deeper yet (15 to $20 \mathrm{~m}$ ).

\section{May}

We used data from the 08:00 h time period to describe diurnal vertical distributions on 22 May, as this coincided with the times that collections were made on the other 3 dates. Descriptions of depth distributions at 
Table 5. Mean densities, in numbers per $100 \mathrm{~m}^{3}$, of fish larvae by depth, with standard errors (in parentheses) and results of statistical tests for samples collected on 15 May 1987. Underlined probabilities resulted from ANOVA on log $(x+1)$-transformed data, others are from Kruskal-Wallis nonparametric tests

\begin{tabular}{|c|c|c|c|c|c|c|c|}
\hline \multirow[t]{2}{*}{ Taxa } & \multicolumn{6}{|c|}{ Depth (m) } & \multirow[t]{2}{*}{$\mathrm{p}$} \\
\hline & 0 & 5 & 10 & 15 & 20 & 30 & \\
\hline Smelt (Osmeridae) & $\begin{array}{c}53.8 \\
(53.8)\end{array}$ & $\begin{array}{l}224.3 \\
(22.0)\end{array}$ & $\begin{array}{r}145.8 \\
(4.5)\end{array}$ & $\begin{array}{c}3.6 \\
(1.3)\end{array}$ & $\begin{array}{c}0 \\
(0)\end{array}$ & $\begin{array}{c}0.2 \\
(0.2)\end{array}$ & $\leq 0.001$ \\
\hline $\begin{array}{l}\text { Pacific herring } \\
\text { Clupea pallasi }\end{array}$ & $\begin{array}{c}0.2 \\
(0.2)\end{array}$ & $\begin{array}{c}0.4 \\
(0.2)\end{array}$ & $\begin{array}{c}0.3 \\
(0.3)\end{array}$ & $\begin{array}{c}0 \\
(0)\end{array}$ & $\begin{array}{c}0 \\
(0)\end{array}$ & $\begin{array}{c}0 \\
(0)\end{array}$ & 0.015 \\
\hline $\begin{array}{l}\text { Walleye pollock } \\
\text { Theragra chalcogramma }\end{array}$ & $\begin{array}{l}2.6 \\
(2.6)\end{array}$ & $\begin{array}{c}9.9 \\
(1.9)\end{array}$ & $\begin{array}{l}15.5 \\
(2.1)\end{array}$ & $\begin{array}{l}11.6 \\
(2.3)\end{array}$ & $\begin{array}{c}0.8 \\
(0.2)\end{array}$ & $\begin{array}{c}0 \\
(0)\end{array}$ & $\leq 0.001$ \\
\hline Poacher (Agonidae) & $\begin{array}{c}0 \\
(0)\end{array}$ & $\begin{array}{c}0 \\
(0)\end{array}$ & $\begin{array}{c}1.8 \\
(0.3)\end{array}$ & $\begin{array}{l}18.7 \\
(7.1)\end{array}$ & $\begin{array}{c}7.9 \\
(1.1)\end{array}$ & $\begin{array}{c}0 \\
(0)\end{array}$ & $\leq 0.001$ \\
\hline $\begin{array}{l}\text { Slender cockscomb } \\
\text { Anoplarchus insignis }\end{array}$ & $\begin{array}{c}0.8 \\
(0.8)\end{array}$ & $\begin{array}{l}2.3 \\
(0.9)\end{array}$ & $\begin{array}{c}1.3 \\
(0.3)\end{array}$ & $\begin{array}{c}0 \\
(0)\end{array}$ & $\begin{array}{c}0 \\
(0)\end{array}$ & $\begin{array}{c}0 \\
(0)\end{array}$ & 0.024 \\
\hline $\begin{array}{l}\text { Longsnout prickleback } \\
\text { Lumpenella longirostris }\end{array}$ & $\begin{array}{c}0 \\
(0)\end{array}$ & $\begin{array}{c}0 \\
(0)\end{array}$ & $\begin{array}{c}0.8 \\
(0.5)\end{array}$ & $\begin{array}{c}1.9 \\
(1.3)\end{array}$ & $\begin{array}{c}0.8 \\
(0.2)\end{array}$ & $\begin{array}{c}0 \\
(0)\end{array}$ & 0.028 \\
\hline $\begin{array}{l}\text { Snake prickleback } \\
\text { Lumpenus sagitta }\end{array}$ & $\begin{array}{c}0 \\
(0)\end{array}$ & $\begin{array}{c}0 \\
(0)\end{array}$ & $\begin{array}{c}0 \\
(0)\end{array}$ & $\begin{array}{c}0.6 \\
(0.6)\end{array}$ & $\begin{array}{c}0.8 \\
(0.2)\end{array}$ & $\begin{array}{c}0 \\
(0)\end{array}$ & 0.034 \\
\hline $\begin{array}{l}\text { Sandlance } \\
\text { Ammodytes hexapterus }\end{array}$ & $\begin{array}{c}0.5 \\
(0.5)\end{array}$ & $\begin{array}{l}3.6 \\
(0.8)\end{array}$ & $\begin{array}{c}0.5 \\
(0.2)\end{array}$ & $\begin{array}{c}0 \\
(0)\end{array}$ & $\begin{array}{c}0 \\
(0)\end{array}$ & $\begin{array}{c}0 \\
(0)\end{array}$ & 0.024 \\
\hline $\begin{array}{l}\text { Northern smoothtongue } \\
\text { Leuroglossus schmidti }\end{array}$ & $\begin{array}{c}0 \\
(0)\end{array}$ & $\begin{array}{c}0 \\
(0)\end{array}$ & $\begin{array}{c}0.3 \\
(0.3)\end{array}$ & $\begin{array}{c}3.0 \\
(0.2)\end{array}$ & $\begin{array}{l}1.7 \\
(1.0)\end{array}$ & $\begin{array}{c}0.2 \\
(0.2)\end{array}$ & $\leq 0.001$ \\
\hline $\begin{array}{l}\text { Rock sole } \\
\text { Pleuronectes bilineatus }\end{array}$ & $\begin{array}{c}0.7 \\
(0.7)\end{array}$ & $\begin{array}{c}1.5 \\
(0.6)\end{array}$ & $\begin{array}{c}2.1 \\
(0.2)\end{array}$ & $\begin{array}{c}1.1 \\
(0.2)\end{array}$ & $\begin{array}{c}0 \\
(0)\end{array}$ & $\begin{array}{c}0 \\
(0)\end{array}$ & 0.005 \\
\hline $\begin{array}{l}\text { Flathead sole } \\
\text { Hippoglossoides elassodon }\end{array}$ & $\begin{array}{l}2.3 \\
(2.3)\end{array}$ & $\begin{array}{l}11.6 \\
(1.3)\end{array}$ & $\begin{array}{l}9.3 \\
(2.7)\end{array}$ & $\begin{array}{c}0.2 \\
(0.2)\end{array}$ & $\begin{array}{c}0 \\
(0)\end{array}$ & $\begin{array}{c}0 \\
0\end{array}$ & $\leq 0.001$ \\
\hline $\begin{array}{l}\text { Starry flounder } \\
\text { Platichthyes stellatus }\end{array}$ & $\begin{array}{c}0.2 \\
(0.2)\end{array}$ & $\begin{array}{l}0.6 \\
10)\end{array}$ & $\begin{array}{l}0.3 \\
(0.3)\end{array}$ & $\begin{array}{c}0.4 \\
(0.4)\end{array}$ & $\begin{array}{c}0 \\
(0)\end{array}$ & $\begin{array}{c}0 \\
(0)\end{array}$ & 0.186 \\
\hline $\begin{array}{l}\text { Sand sole } \\
\text { Psettichthys melanostictus }\end{array}$ & $\begin{array}{c}0 \\
(0)\end{array}$ & $\begin{array}{l}1.7 \\
(0.9)\end{array}$ & $\begin{array}{l}2.3 \\
(0.4)\end{array}$ & $\begin{array}{c}0 \\
(0)\end{array}$ & $\begin{array}{c}0 \\
(0)\end{array}$ & $\begin{array}{c}0 \\
(0)\end{array}$ & 0.022 \\
\hline Sculpins (Cottidae) & $\begin{array}{c}0.5 \\
(0.5)\end{array}$ & $\begin{array}{c}4.1 \\
(1.2)\end{array}$ & $\begin{array}{l}5.7 \\
(1.6)\end{array}$ & $\begin{array}{c}8.2 \\
(0.6)\end{array}$ & $\begin{array}{c}1.7 \\
(0.8)\end{array}$ & $\begin{array}{c}0 \\
(0)\end{array}$ & 0.014 \\
\hline Snailfishes (Cyclopteridae) & $\begin{array}{c}0 \\
(0)\end{array}$ & $\begin{array}{c}0.2 \\
(0.2)\end{array}$ & $\begin{array}{c}1.8 \\
(0.2)\end{array}$ & $\begin{array}{c}1.1 \\
(0.2)\end{array}$ & $\begin{array}{c}0.4 \\
(0.4)\end{array}$ & $\begin{array}{c}0 \\
(0)\end{array}$ & 0.015 \\
\hline
\end{tabular}

this time are included in the preceding section on vertical migration, and summarized in Fig. 6.

\section{June}

In early June osmerids were at their seasonal peak, with very high relative abundance. Walleye pollock and flathead sole were also at their maximum, as were sand sole Psettichthys melanostictus and cottids (Table 6). Osmerid peak numbers were still found at $5 \mathrm{~m}$. Walleye pollock depth distribution was very similar to that in May, with highest abundance from 5 to $15 \mathrm{~m}$. Flathead sole were again concentrated at $5 \mathrm{~m}$, as were sand sole and herring Clupea harengus.
Agonids and northern smoothtongue were at 20 to $30 \mathrm{~m}$.

The mean depth of osmerid larvae (the only taxon that ascended at night) was deeper on each successive sampling date (Fig. 8). Among the 6 physical and biotic variables, pycnocline depth had the highest coefficient of determination in the series of linear regressions (Table 7).

Mean depths of the next 5 most abundant taxa (walleye pollock, flathead sole, rock sole, agonids and northern smoothtongue, all of which descended at dusk) were in the same rank order in all 4 of the weekly daytime samples (Fig. 8). This pattern is highly significant, as the probability of observing the same rank order 4 consecutive times among 5 randomly assorting variables is extremely small $(\mathrm{p}<0.00001)$. The most pro- 
Table 6. Mean densities, in numbers per $100 \mathrm{~m}^{3}$, of fish larvae by depth, with standard errors (in parentheses) and results of statistical tests for samples collected on 5 June 1987. Underlined probabilities resulted from ANOVA on log $(x+1)$-transformed data, others are from Kruskal-Wallis nonparametric tests

\begin{tabular}{|c|c|c|c|c|c|c|c|}
\hline \multirow[t]{2}{*}{ Taxa } & \multicolumn{6}{|c|}{ Depth $(\mathrm{m})$} & \multirow[t]{2}{*}{$\mathrm{p}$} \\
\hline & 0 & 5 & 10 & 15 & 20 & 30 & \\
\hline Smelt (Osmeridae) & $\begin{array}{c}2.1 \\
(1.4)\end{array}$ & $\begin{array}{l}519.2 \\
(43.2)\end{array}$ & $\begin{array}{l}353.2 \\
(45.0)\end{array}$ & $\begin{array}{l}167.70 \\
(18.4)\end{array}$ & $\begin{array}{r}207.8 \\
(9.2)\end{array}$ & $\begin{array}{c}5.8 \\
(3.7)\end{array}$ & $\leq 0.001$ \\
\hline $\begin{array}{l}\text { Pacific herring } \\
\text { Clupea pallasi }\end{array}$ & $\begin{array}{c}1.0 \\
(0.8)\end{array}$ & $\begin{array}{l}24.9 \\
(8.1)\end{array}$ & $\begin{array}{l}12.9 \\
(0.8)\end{array}$ & $\begin{array}{l}3.4 \\
(1.7)\end{array}$ & $\begin{array}{c}0 \\
(0)\end{array}$ & $\begin{array}{c}0 \\
(0)\end{array}$ & 0.020 \\
\hline $\begin{array}{l}\text { Walleye pollock } \\
\text { Theragra chalcogramma }\end{array}$ & $\begin{array}{c}0 \\
(0)\end{array}$ & $\begin{array}{l}20.6 \\
(2.7)\end{array}$ & $\begin{array}{l}27.5 \\
(4.5)\end{array}$ & $\begin{array}{l}20.8 \\
(1.5)\end{array}$ & $\begin{array}{l}13.7 \\
(3.5)\end{array}$ & $\begin{array}{c}0.8 \\
(0.5)\end{array}$ & $\leq 0.001$ \\
\hline Poacher (Agonidae) & $\begin{array}{c}0 \\
(0)\end{array}$ & $\begin{array}{c}0.6 \\
(0.3)\end{array}$ & $\begin{array}{c}0.2 \\
(0.2)\end{array}$ & $\begin{array}{c}0.6 \\
(0.3)\end{array}$ & $\begin{array}{l}2.7 \\
(0.1)\end{array}$ & $\begin{array}{c}2.6 \\
(0.2)\end{array}$ & $\leq 0.001$ \\
\hline $\begin{array}{l}\text { Northern ronquil } \\
\text { Ronquilus jordani }\end{array}$ & $\begin{array}{c}0 \\
(0)\end{array}$ & $\begin{array}{c}4.1 \\
(1.2)\end{array}$ & $\begin{array}{l}2.7 \\
(0.5)\end{array}$ & $\begin{array}{c}0.9 \\
(0.6)\end{array}$ & $\begin{array}{c}0.4 \\
(0.4)\end{array}$ & $\begin{array}{c}0 \\
(0)\end{array}$ & 0.014 \\
\hline $\begin{array}{l}\text { Northern smoothtongue } \\
\text { Leuroglossus schmidti }\end{array}$ & $\begin{array}{c}0 \\
(0)\end{array}$ & $\begin{array}{c}0 \\
(0)\end{array}$ & $\begin{array}{c}0 \\
(0)\end{array}$ & $\begin{array}{c}0 \\
(0)\end{array}$ & $\begin{array}{c}1.4 \\
(0.8)\end{array}$ & $\begin{array}{c}1.7 \\
(0.3)\end{array}$ & 0.022 \\
\hline $\begin{array}{l}\text { Rock sole } \\
\text { Pleuronectes bilineatus }\end{array}$ & $\begin{array}{c}0 \\
(0)\end{array}$ & $\begin{array}{c}1.3 \\
(0.6)\end{array}$ & $\begin{array}{l}1.7 \\
(0.4)\end{array}$ & $\begin{array}{c}0.2 \\
(0.2)\end{array}$ & $\begin{array}{c}0.2 \\
(0.2)\end{array}$ & $\begin{array}{c}0 \\
(0)\end{array}$ & $\underline{0.193}$ \\
\hline $\begin{array}{l}\text { Flathead sole } \\
\text { Hippoglossoides elassodon }\end{array}$ & $\begin{array}{c}0.1 \\
(0.1)\end{array}$ & $\begin{array}{l}64.2 \\
(3.7)\end{array}$ & $\begin{array}{l}47.7 \\
(8.9)\end{array}$ & $\begin{array}{l}10.0 \\
(4.6)\end{array}$ & $\begin{array}{c}2.1 \\
(0.7)\end{array}$ & $\begin{array}{c}0 \\
(0)\end{array}$ & $\leq 0,001$ \\
\hline $\begin{array}{l}\text { Starry flounder } \\
\text { Platichthyes stellatus }\end{array}$ & $\begin{array}{c}0 \\
(0)\end{array}$ & $\begin{array}{c}1.9 \\
(1.3)\end{array}$ & $\begin{array}{c}0.2 \\
(0.2)\end{array}$ & $\begin{array}{c}0 \\
(0)\end{array}$ & $\begin{array}{c}0 \\
(0)\end{array}$ & $\begin{array}{c}0 \\
(0)\end{array}$ & 0.164 \\
\hline $\begin{array}{l}\text { Sand sole } \\
\text { Psettichthys melanostictus }\end{array}$ & $\begin{array}{c}0 \\
(0)\end{array}$ & $\begin{array}{c}9.9 \\
(3.9)\end{array}$ & $\begin{array}{l}5.3 \\
(2.2)\end{array}$ & $\begin{array}{c}0.4 \\
(0.5)\end{array}$ & $\begin{array}{c}0.2 \\
(0.2)\end{array}$ & $\begin{array}{c}0 \\
(0)\end{array}$ & 0.014 \\
\hline Sculpins (Cottidae) & $\begin{array}{c}0 \\
(0)\end{array}$ & $\begin{array}{l}21.9 \\
(4.9)\end{array}$ & $\begin{array}{c}4.6 \\
(0.7)\end{array}$ & $\begin{array}{c}0.6 \\
(0.6)\end{array}$ & $\begin{array}{c}0 \\
(0)\end{array}$ & $\begin{array}{c}0 \\
(0)\end{array}$ & 0.008 \\
\hline Snailfishes (Cyclopteridae) & $\begin{array}{c}0 \\
(0)\end{array}$ & $\begin{array}{c}0.2 \\
(0.2)\end{array}$ & $\begin{array}{c}0.4 \\
(0.4)\end{array}$ & $\begin{array}{c}0.2 \\
(0.2)\end{array}$ & $\begin{array}{l}0.7 \\
(0)\end{array}$ & $\begin{array}{c}0 \\
(0)\end{array}$ & 0.098 \\
\hline
\end{tabular}

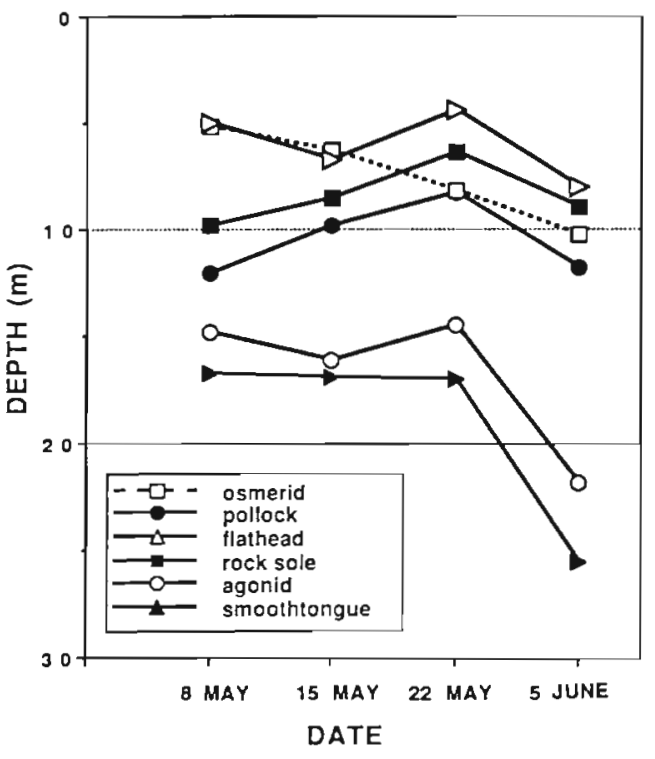

Fig. 8. Mean depths of the 6 most abundant taxa in Auke Bay during the day on 8, 15, 22 May and 5 June 1987 nounced shift in depth among these 5 taxa occurred in the last period (June 5), when their mean depth increased. Among the suite of environmental variables, linear regression with the depth of the 6 or $5^{\circ} \mathrm{C}$ isotherm produced the highest coefficient of determination in all 5 taxa (Table 7). The colder of the 2 isotherms accounted for more of the variability in depth of the 2 taxa with the deepest distributions (agonids and northern smoothtongue) than did any other variable.

\section{DISCUSSION}

We observed 2 types of vertical migration. Only 1 taxon, osmerids, ascended at night. This pattern has been most frequently reported for larval fishes (Neilson \& Perry 1990). Osmerids include species that are freshwater, anadromous and marine. In Auke Bay, osmerids apparently occur predominantly in the mixed layer, rising to the surface at night and returning to relatively shallow depths during the day. Consequently, they occupy the warmest and freshest part of 
Table 7. Values of $\mathrm{r}^{2}$ from simple regression models with mean depth of 6 larval fish taxa on $8,15,22$ May and 5 June as the dependent variable and the depth of 6 environmental variables in Table 2 as the independent variable. Environmental variables: PYCNO, pycnocline; TEMP, 6 and $5^{\circ} \mathrm{C}$ isotherms; LIGHT, depth of the isolume; WIND, wind speed; PHYTO, depth of the phytoplankton maximum; COPE, mean depth of copepod nauplii. The highest value for each taxon is underlined

\begin{tabular}{|lccccccc|}
\hline & \multirow{2}{*}{ PYCNO } & \multicolumn{2}{c}{ TEMP } & LIGHT & WIND & PHYTO COPE \\
\hline Osmerid & & $6^{\circ} \mathrm{C}$ & $5^{\circ} \mathrm{C}$ & & & & \\
Walleye pollock & $\underline{0.53}$ & $<0.01$ & 0.28 & 0.27 & 0.02 & 0.01 & 0.39 \\
Flathead sole & 0.53 & $\underline{0.95}$ & 0.62 & 0.33 & 0.05 & 0.86 & 0.26 \\
Rock sole & $<0.01$ & 0.40 & $\underline{0.68}$ & 0.21 & 0.40 & 0.02 & 0.28 \\
Agonid & 0.75 & $\underline{0.89}$ & 0.41 & 0.28 & $<0.01$ & 0.65 & 0.25 \\
Northern smoothtongue & 0.04 & 0.36 & $\underline{0.84}$ & 0.11 & 0.10 & 0.09 & 0.20 \\
& 0.07 & 0.30 & $\underline{0.81}$ & 0.06 & 0.02 & 0.12 & 0.14 \\
\hline
\end{tabular}

the water column (the mixed layer). Other osmerids have vertical migration patterns that are consistent with these observations. In the St. Lawrence estuary, Canada, rainbow smelt Osmerus mordax use tidal vertical migration to move upstream into warmer, fresher water (Laprise \& Dodson 1989), while capelin Mallotus villosus migrated vertically within the surface layer (Fortier \& Leggett 1983).

Descent at dusk was the most common form of vertical migration among larval fishes in Auke Bay. Species that descended at dusk included walleye pollock, flathead sole, rock sole, agonids and northern smoothtongue. Deeper depth distributions at night have been reported for larval fishes (Neilson \& Perry 1990) including sandlance (Yamashita et al. 1985), Pacific cod (Boehlert et al. 1985), Atlantic herring (Munk et al. 1989), red drum (Lyczkowski-Shultz \& Steen 1991) and gulf menhaden (Sogard et al. 1987); however, it is more common for larval fishes to be nearer the surface at night (Neilson \& Perry 1990). Studies in Shelikof Strait of the North Pacific Ocean have found most species of larval fishes to be deeper at night, including rock sole, flathead sole, Pacific sandlance and searchers (Bathymasteridae) (Richard Brodeur, Alaska Fisheries Science Center, National Marine Fisheries Service, 7600 Sand Point Way NE, Seattle, WA 98115, USA, pers. comm.). In Auke Bay, rock sole was the only species that remained at depth throughout the night. By the 24:00 h sampling period the other taxa that descended at dusk had either returned to, or were intermediate to, typical daytime depths.

Larval fishes may become less aggregated nocturnally (Brewer \& Kleppel 1986, Kendall et al. 1987, Heath et al. 1988, Leis 1991). Among the 6 most abundant species in Auke Bay there are indications that nocturnal distributions were more diffuse. Four of the 6 cases where there were no significant differences in abundance among depths occurred at 20:00 and $24: 00 \mathrm{~h}$, and 7 of the 12 cases where a posteriori tests found no pairwise differences were also at 20:00 and 24:00 h (Table 3). This trend could have resulted from reduced aggregation or from higher interreplicate variance at night. To determine the cause we compared the coefficient of variation between diurnal $(04: 00,08: 00,12: 00,16: 00 \mathrm{~h})$ and nocturnal $(20: 00$, 24:00 h) samples, as an increase in the coefficient would be associated with higher interreplicate variance. We found no increase in the coefficient of variation in nocturnal samples, with the exception of northern smoothtongue at 24:00 h, where the average coefficient was unusually high and was almost certainly responsible for the lack of significant difference among depths for that species at 24:00 h. Therefore we conclude that there was a tendency for larvae to become less aggregated nocturnally. This was most pronounced in flathead sole.

The relatively shallow depth distributions of walleye pollock were similar to depths they occupy in Uchiura Bay, Japan (Kamba 1977) and in the Bering Sea (Dagg et al. 1984, Nishiyama et al. 1986). However, in Shelikof Strait, Alaska, they were usually deeper (Kendall et al. 1987). Rock sole and flathead sole had relatively shallow depth distributions in Auke Bay, a pattern observed off Oregon, USA, for rock sole (Boehlert et al. 1985) and in Shelikof Strait for both species (R. Brodeur pers. comm.). Agonids and northern smoothtongue were consistently deeper than most other taxa. Northern smoothtongue are bathylagids, a family with larvae that are found relatively deep off Peru (Sameoto 1982) and Oregon (Boehlert et al. 1985).

Diurnally, larval fishes have often been found concentrated at depths where prey is relatively abundant (e.g. Kamba 1977, Fortier \& Leggett 1983, Munk et al. 1989). In Auke Bay, most fish larvae were found at depths with relatively high concentrations of copepod nauplii. Osmerids, walleye pollock, flathead sole and rock sole were consistently aggregated at depths with 
high prey abundance, whereas agonids and northern smoothtongue consistently occurred deeper than most copepod nauplii.

Fish larvae may acccumulate where prey are concentrated by modifying their behaviour when they find good foraging conditions (Munk \& Kiørboe 1985, Batty 1987), or by associating with physical conditions, such as a thermocline, where prey aggregate (Peterson \& Ausubel 1984, Frank et al. 1989, Munk et al. 1989) Physical factors that may affect depth of larval fishes include light (Heath et al. 1988, Munk et al. 1989 Olla \& Davis 1990), temperature (Ahlstrom 1959, Kendall \& Naplin 1981, Olla \& Davis 1990) and turbulence (Heath et al. 1988, Olla \& Davis 1990).

The persistent rank order of mean daytime depth among the 5 taxa that descended at dusk suggests their depth distributions were determined by the same environmental conditions. Of the variables we measured, temperature was implicated by high coefficients of determination $\left(\mathrm{r}^{2}\right)$ in the series of regressions, with depth of the colder of the 2 isotherms accounting for more variation in the deepest-distributed taxa. Fishes, like most poikilotherms, display a preference for ranges of temperatures that are often associated with physiological and growth optima (Brett 1970, Crawshaw 1977, Reynolds \& Casterlin 1977). Larval fishes will adjust their depth to avoid unfavorable temperatures (Olla \& Davis 1990), and they concentrate at thermoclines (Ahlstrom 1959, Kendall \& Naplin 1981, Boehlert et al. 1985, Perry \& Neilson 1988). Below the pycnocline temperatures gradually decreased from around 7 to just above $4{ }^{\circ} \mathrm{C}$ (Figs. $2 \& 3$ ). Fishes have the ability to discern small changes of temperature, so it is not unreasonable to suggest that their depth distributions in Auke Bay were a function of temperature preferences.

Although our results suggest that larval fishes select their daytime depths based on temperature preferences, there were indications that light may also have had some effect. Some of the species displayed an increase in depth around midday (e.g. walleye pollock, rock sole); this could result from negative phototaxis at high light levels, as observed in walleye pollock larvae under laboratory conditions (Olla \& Davis 1990). Atlantic herring larvae have displayed complex vertical distributional patterns that apparently are a response to multiple and interacting variables including light, turbulence and distribution of prey (Heath et al. 1988, Munk et al. 1989). It is likely that the larvae we observed in Auke Bay also respond to a variety of extrinsic variables, and it would be naive to suggest that they display an absolute response to temperature. For example, in less-protected waters than Auke Bay, turbulence and wind mixing may have important effects on vertical distribution. Also, in areas such as the Bering Sea, larvae (i.e. walleye pollock) that we observed below the pycnocline are common in the mixed layer. In such systems vertical distribution and migration may differ markedly from patterns we observed in a shallow protected embayment where most larvae were below the mixed layer.

The widespread occurrence of diel vertical migration among fishes and other taxa suggests that there are adaptive advantages associated with this behavior. Possibilities include enhancement of feeding (although for fishes this is most often associated with nocturnal or crepuscular feeding; see review by Neilson \& Perry 1990) avoidance of predators (Hunter \& Sanchez 1976, Yamashita et al. 1985), metabolic advantages (Wurtsbaugh \& Neverman 1988), transport (Fortier \& Leggett 1983, Boehlert \& Mundy 1988) and retention (Sinclair 1988, Stephenson \& Power 1989). Our data do not provide any clear distinction among these possibilities. However, in Auke Bay the diel vertical migrations performed by larval fishes appear to affect 2 important processes. (1) Feeding: larval fishes generally are found at depths with high abundance of copepod nauplii during diurnal feeding periods. (2) Avoidance of predators: fish larvae that descend at dusk appear to minimize their spatial overlap with a suite of micronektonic predators that migrate from deep to shallow water at dusk. These predators include euphausiids (Paul et al. 1990b) and small fishes such as juvenile herring, capelin and salmonids (Coyle \& Paul 1992).

Acknowledgements. This study was part of the APPRISE program, a collaborative research program by the Juneau Center for Fisheries and Ocean Sciences, University of Alaska Fairbanks; The Institute of Marine Science, University of Alaska Fairbanks; and the Oceanic Institute, Waimanalo, Hawaii. The National Marine Fisheries Service, Auke Bay Laboratory provided logistic support. This program was supported by Contract No. NA-85-ABH-00022 from the U.S. Department of Commerce, National Oceanic and Atmospheric Administration. In the field we were assisted by Donald Erickson, Thomas Shirley, David Sterritt and John Watts. In the laboratory the help of Amanda Arra was greatly appreciated.

\section{LITERATURE CITED}

AhIstrom, E. H. (1959). Vertical distribution of pelagic fish eggs and larvae off California and Baja California. Fishery Bull. Fish Wildl. Ser. U.S. 60: 107-146

Bagarinao, T., Hunter, J. R. (1983). The visual feeding threshold and action spectrum of northern anchovy (Engraulis mordax) larvae. CalCOFI Rep. XXIV: 245-254

Barnett, A. M., Jahn, A. E., Sertic, P. D., Watson, W. (1984). Distribution of ichthyoplankton off San Onofre, California, and methods for sampling very shallow coastal waters. Fish. Bull. U.S. 82: 97-109

Batty, R. S. (1987). Effect of light intensity on activity and food-searching of larval herring, Clupea harengus: a laboratory study. Mar. Biol. 94: 323-327 
Blaxter, J. H. S. (1968). Visual thresholds and spectral sensitivity of herring larvae. J. exp. Biol. 48: 39-53

Boehlert, G. W., Gadomski, D. M., Mundy, B. C. (1985). Vertical distribution of ichthyoplankton off the Oregon coast in spring and summer months. Fish. Bull. U.S. 83: $611-621$

Boehlert, G. W., Mundy, B. C. (1988). Roles of behavioral and physical factors on larval and juvenule fish recruitment to estuarine nursery areas. Am. Fish. Symp. 3: 16-25

Brett, J. R. (1970). Temperature. Fishes. In: Kinne, O. (ed.) Marine ecology. Wiley-Interscience, New York, p. 515-616

Brewer, G. D., Kleppel, G. S. (1986). Diel vertical distribution of fish larvae and their prey in nearshore waters of southern California. Mar. Ecol. Prog. Ser. 27: 217-226

Bruce, H. W., McLain, D. R., Wing, B. L. (1977). Annual physical and chemical oceanographic cycles of Auke Bay, southeastern Alaska. NOAA Tech. Rep. NMFS SSRF-712

Coyle, K. O., Paul, A. J. (1990). Interannual variations in zooplankton population and biomass during the spring bloom in an Alaskan subarctic embayment. In: Ziemann, D. A., Fulton-Bennett, K. W. (eds.) APPRISE - interannual variability and fisheries recruitment. The Oceanic Institute, Honolulu, p. 179-228

Coyle, K. O., Paul, A. J. (1992). Interannual differences in prey taken by capelin, herring, and red salmon relative to zooplankton abundance during the spring bloom in a southeast Alaskan embayment. Fish. Oceanogr. 1: 294-305

Coyle, K. O., Paul, A. J., Ziemann. D. (1990) Interannual variation in copepod population during the spring bloom in an Alaskan subarctic embayment. J. Plankton Res. 12: $759-797$

Crawshaw, L. I. (1977). Physiological and behavioral reactions of fishes to temperature change. J. Fish. Res. Bd Can. 34: $730-734$

Cushing, D. H. (1975). Marine ecology and fisheries. Cambridge University Press, Cambridge

Dagg, M. J., Clarke, M. E., Nishiyama, T., Smith, S. L. (1984). Production and standing stock of copepod nauplii, food items for larvae of the walleye pollock Theragra chalcogramma in the southeastern Bering Sea. Mar. Ecol. Prog. Ser. 19: 7-16

de Lafontaine, Y., Gascon, D. (1989). Ontogenic variation in the vertical distribution of eggs and larvae of Atlantic mackerel (Scombrus scombrus). Rapp. P.-v. Réun. Cons. int. Explor. Mer 191: 137-145

Ellertsen, B., Solemdal, P., Sundby, S., Tilseth, S., Westgard, T., Oiestad, V. (1981). Feeding and vertical distribution of cod larvae in relation to availability of prey organisms. Rapp. P.-v. Réun. Cons, int. Explor. Mer 178: 317-319

Fortier, L., Leggett, W. D. (1983). Vertical migrations and transport of larval fish in a partially mixed estuary. Can. J. Fish. Aquat. Sci. 40: 1543-1555

Frank, K. I., McRuer, J. K. (1989). Nutritional status of fieldcollected haddock (Melanogrammus aeglefinus) larvae from southwestern Nova Scotia: an assessment based on morphometric and vertical distribution data. Can. J. Fish. Aquat. Sci. 46(Suppl. 1): 125-133

Frank, K. T., Page, F. H., McRuer, J. K. (1989). Hydrographic effects on the vertical distribution of haddock (Melanogramnus aeglefinus) eggs and larvae on the southwestern Scotian Shelf. Can. J. Fish. Aquat. Sci. 46 (Suppl. 1): $82-92$

Haldorson, L., Paul, A. J., Sterritt, D., Watts, J. (1989). Annual and seasonal variation in growth of larval walleye pollock and flathead sole in a southeast Alaskan bay. Rapp. P.-v. Réun. Cons. int. Explor. Mer 191: 220-225

Haldorson, L., Pritchett, M., Sterritt, D., Watts, J. (1993).
Abundance of marine fish larvae during spring in a southeastern Alaskan bay. Fish. Bull. U.S. (in press)

Heath, M. R., Henderson, E. W., Baird, D. L. (1988). Vertical distribution of herring larvae in relation to physical mixing and illumination. Mar. Ecol. Prog. Ser. 47: 211-228

Hunter, J. R., Sanchez, C. (1976). Diel changes in swim bladder inflation of the larvae of the northern anchovy, Engraulis mordax. Fish. Bull. U.S. 74: 847-855

Kamba, M. (1977). Feeding habits and vertical distribution of walleye pollock, Theragra chalcogramma (Pallas), in early life stage in Uchiura Bay, Hokkaido. Res. Inst. N. Pac. Fish., Hokkaido Univ., Spec. Vol. 175-197

Kendall, A. W. Jr, Clarke, M. E., Yoklavich, M. M., Boehlert, G. W. (1987). Distribution, feeding and growth of larval walleye pollock, Theragra chalcogramma, from Shelikof Strait, Gulf of Alaska. Fish. Bull. U.S. 85: 499-521

Kendall, A. W. Jr, Naplin, N. A. (1981). Diel-depth distribution of summer ichthyoplankton in the middle Atlantic Bight. Fish. Bull. U.S. 79: 705-726

Laprise, R., Dodson, J. J. (1989). Ontogenetic changes in the longitudinal distribution of two species of larval fish in a turbid well-mixed estuary. J. Fish. Biol. 35(Suppl. A): 39-47

Lasker, R. (1978). The relation between oceanographic conditions and larval anchovy food in the California Current: identification of factors contributing to recruitment failure. Rapp. P.-v. Réun. Cons. int. Explor. Mer 173: 212-230

Leis, J. M. (1991). Vertical distribution of fish larvae in the Great Barrier Reef Lagoon, Australia. Mar. Biol. 109: $157-166$

Lyczkowski-Shultz, J., Steen, J. P. Jr (1991) Diel vertical distribution of red drum Sciaenops ocellatus larvae in the northcentral Gulf of Mexico. Fish. Bull. U.S. 89: 631-641

McCleave, J. D., Bedaux, J. J. M., Doucet, P. G., Jager, J. C., Jong, J. T L., van der Steen, W. J., Voorznager, B. (1987). Statistical methods for analysis of plankton and nekton distribution, with application to selective tidal stream transport of juvenile American eels (Anguilla rostrata). J. Cons. int. Explor. Mer 44: 90-103

Munk, P., Kirrboe, T. (1985). Feeding behavior and swimming activity of larval herring (Clupea harengus) in relation to density of copepod nauplii. Mar. Ecol. Prog. Ser. 24: $15-21$

Munk, P., Kiørboe, T., Christensen, V (1989). Vertical migrations of herring, Clupea harengus, larvae in relation to light and prey distribution. Env. Biol. Fish. 26: 87-96

Neilson, J. D., Perry, R. 1. (1990). Diel vertical migrations of marine fishes: an obligate or facultative process? Adv. mar. Biol. 26: 115-168

Nishiyama, T., Hirano, K., Haryu, I (1986). The early life history and feeding habits of larval walleye pollock Theragra chalcogramma (Pallas) in the southeast Bering Sea. Int. N. Pac. Fish. Comm. Bull. 45: 177-227

Olla, B. L., Davis, M. W. (1990). Effects of physical factors on the vertical distribution of larval walleye pollock Theragra chalcogramma under controlled laboratory conditions. Mar. Ecol. Prog. Ser. 63: 105-112

Paul, A. J., Coyle, K. O., Haldorson, L. (1991). Interannual variations in copepod nauplii prey of larval fish in an Alaskan bay. ICES J. mar. Sci. 48: 157-165

Paul, A. J., Coyle, K. O., Ziemann, D. A. (1990a). Variations in egg production rates by Pseudocalanus spp. in a subarctic Alaskan bay during the onset of feeding by larval fish. J. Crust. Biol. 10: 648-658

Paul, A. J., Coyle, K. O., Ziemann, D. A. (1990b). Timing of spawning of Thysanoessa raschii (Euphausiacea) and occurrence of their feeding-stage larvae in an Alaskan bay. J Crust Biol. 10: 69-78 
Perry, R. I., Neilson, J. D (1988). Vertical distributions and trophic interactions of age-O Atlantic cod and haddock in mixed and stratified waters of Georges Bank. Mar. Ecol. Prog. Ser. 49: 199-214

Peterman, R. M., Bradford, M. J. (1987). Wind speed and mortality rate of a marine fish, the northern anchovy (Engraulis mordax). Science 235: 354-356

Peterson, W. T., Ausubel. S. J (1984). Diets and selective feeding by larvae of Atlantic mackerel Scomber scombrus on zooplankton. Mar. Ecol. Prog. Ser. 17: 65-75

Qasim, S. Z. (1956). Time and duration of the spawning season in some marine teleosts in relation to their distribution. J. Cons. perm. int. Explor. Mer 21: 144-155

Reynolds, W. W., Casterlin, M. E. (1977). Responses of young California grunion, Leuresthes tenuis, to gradients of temperature and light. Copeia 1977: 144-149

Sameoto, D. (1982). Vertical distribution and abundance of the Peruvian anchovy, Engraulis ringens, and sardine, Sardinops sagax, larvae during November 1977 J. Fish. Biol. 21: 171-185

Sinclair, M. (1988). Marine populations: an essay on population regulation and speciation. University of Washington Press, Seattle

Sogard, S. M., Hoss, D. E., Govoni, J. J (1987). Density and depth distribution of larval gulf menhaden, Brevoortia patronus, Atlantic croaker, Micropogonias undulatus, and spot, Leiostomus xanthurus, in the northern Gulf of Mexico. Fish. Bull. U.S. 85: 601-609

Stephenson, R. L., Power, M. J. (1989). Observations on herring larvae retained in the Bay of Fundy: variablity in vertical movement and positon of the patch edge. Rapp. P.-v. Réun. Cons. int. Explor. Mer 191: 177-183

Strickland, J. D. H., Parsons, T R. (1972). A practical handbook of seawater analysis, 2nd edn. Bull. Fish. Res. Bd Can. 167: 1-310

Tilseth, S., Ellertsen, B. (1984). The detection and distribution of larval Arcto-Norwegian cod, Gadus morhua, food organisms by an in situ particle counter. Fish. Bull. U.S 82: $141-156$

Williamson, R. S. (1978). Phytoplankton and productivity in Auke Bay, Alaska. MR-F 157, NOAA/NMFS Auke Bay Lab., Juneau, Alaska

Wurtsbaugh, W. A., Neverman, D. (1988). Post-feeding thermotaxis and daily vertical migration in a larval fish Nature 333: 846-848

Yamashita, Y., Kitagawa, D., Aoyama, T. (1985). Diel vertical migration and feeding rhythm of the larvae of the Japanese sand-eel Ammodytes personatus. Bull. Jap. Soc. scient. Fish. 51: 1-5

Ziemann, D. A., Conquest, L. D., Fulton-Bennett, K. W., Bienfang, P. K. (1990). Interannual variability in the physical environment of Auke Bay, Alaska. In: Ziemann, D. A., Fulton-Bennett, K. W. (eds.) APPRISE - interannual variability and fisheries recruitment. The Oceanic Institute, Honolulu, interannual p. 99-128

Ziemann, D. A., Conquest, L. D., Olaizola, M., Bienfang, P. K. (1991). Interannual variability in the spring phytoplankton bloom in Auke Bay, Alaska. Mar. Biol. 109: 321-334

Manuscript first received: April 29, 1992

Revised version accepted: July 16, 1993 